\title{
APRENDIZAGEM ESCOLAR NO CIBERESPAÇO: CONTROVÉRSIAS REVELADAS POR ALUNOS(AS) DO ENSINO FUNDAMENTAL
}

\author{
SCHOOL LEARNING IN CIBERESPAÇO: CONTROVERSIES REVEALED BY STUDENTS OF FUNDAMENTAL TEACHING
}

APRENDIZAJE ESCOLAR EN EL CIBERESPAÇO: CONTROVERSIAS REVELADAS POR ALUMNOS / AS DE LA ENSEÑANZA FUNDAMENTAL

\author{
SCHLIECK, Diane ${ }^{1}$ \\ BORGES, Martha Kaschny2
}

\begin{abstract}
RESUMO
Este artigo analisa as controvérsias reveladas, pelos alunos do Ensino Fundamental, nas associações de aprendizagens escolares que realizam no ciberespaço. É fundamentado na Teoria Ator-Rede, de Bruno Latour, e nos estudos de Lúcia Santaella, sobre os sujeitos leitores. A metodologia utilizada foi um estudo de caso de cunho qualitativo, e os dados foram coletados por meio da técnica de grupo focal. A análise dos resultados foi realizada a partir das controvérsias reveladas pelos alunos identificados como imersivos e/ou ubíquos. Os resultados revelam que os alunos gostariam de ser mais "ouvidos" nos espaços escolares, e se sentirem protagonistas de seus processos de ensino e aprendizagem.
\end{abstract}

Palavras-chave: Ciberespaço. Teoria Ator-Rede. Aprendizagem escolar. Aluno. Leitor imersivo e leitor ubíquo.

\section{ABSTRACT}

This article analyses the disputes revealed, by students from Junior High School associated with their learning through cyberspace. This article is based on Bruno Latour's Actor-Network Theory and Lúcia Santaella's studies on reader subjects. The methodology used was a qualitative case study, and the data was collected through the focus group technique. The analysis of the results is based on the disputed revealed by the students identified as immersive and / or omnipresence. The main results reveal that students would like to be more "heard" in school spaces, in order to be acknowledge during their learning processes.

Keywords: Cyberspace. Actor-Network theory. School learning. Student. Immersive reader and omnipresence reader.

\section{RESUMEN}

Este artículo analiza las controversias reveladas, por los alumnos de la Educación Fundamental, en las asociaciones de los aprendizajes escolares que realizan en el cyber-espacio. Este artículo esta fundamentado en la Teoría del Actor-Red de Bruno Latour, y en los estudios de Lúcia Santaella, sobre los sujetos lectores. La metodología utilizada fue un estudio de caso cualitativo, y los datos fueron colectados por medio de la técnica de grupo focal. El análisis de los resultados fue realizado a partir de las controversias reveladas por los alumnos identificados como inmersos y/o ubicuo. Los resultados revelan que a los alumnos les gustaría ser más escuchados en los espacios escolares, y sentirse protagonistas de sus procesos de enseñanza y aprendizaje.

Palabras clave: Cyber-espacio. Teoría Actor-Red. Aprendizaje escolar. Estudiante. Lector inmerso y lector ubicuo.

\footnotetext{
1 Universidade do Estado de Santa Catarina - Udesc - Florianópolis - Santa Catarina - Brasil.

2 Universidade do Estado de Santa Catarina - Udesc - Florianópolis - Santa Catarina - Brasil.
} 


\section{INTRODUÇÃO}

$\mathrm{O}$ atual momento educacional caracteriza-se por profundas e constantes mudanças. Educar alunos na atualidade exige novas formas de promover a educação, de conceber a construção do conhecimento, novas práticas educativas que integrem as tecnologias digitais - TD nos processos educativos, possibilitando aos alunos, a apropriação do conhecimento de maneira mais colaborativa e significativa.

As TD exercem um papel de destaque nos movimentos de transformação das relações entre os sujeitos e o conhecimento e seu uso, compreende processos de ressignificação e adaptação dos esquemas mentais mobilizados pelos sujeitos quando estes utilizam os diferentes instrumentos que têm a sua disposição (BORGES, 2007).

Fomentar o uso das TD nas escolas pode possibilitar que os sujeitos envolvidos se reconheçam, gradativamente, como protagonistas do seu processo de ensino e aprendizagem e, assim, estabeleçam relações mais significativas com o conhecimento. Conhecer e compreender os alunos, a maneira como vêm e organizam seus pensamentos com advento das TD, é importante para que possamos discutir as mudanças que esse momento provoca na escola. $\mathrm{O}$ acesso às informações está facilitado e

[...] a escola deixou de ser o único local de legitimação do saber, pois existe uma multiplicidade de saberes que circulam por outros canais, difusos e descentralizados. A diversificação e difusão do saber, fora da escola, é um dos desafios mais fortes que o mundo da comunicação apresenta ao sistema educacional. (MARTIN-BARBERO, 2011, p. 126).

Neste contexto, a pesquisa que apresentamos neste artigo revela que, navegar no ciberespaço, exige novas maneiras de olhar a construção do conhecimento, novas maneiras de ler, escrever e compartilhar o saber; exige a criação de novas situações de aprendizagem que orientem a navegação e promovam as conexões necessárias para que os alunos se apropriem do conhecimento.

A pesquisa teve como principal objetivo, analisar as controvérsias reveladas pelos alunos imersivos e pelos alunos ubíquos no que tange às associações que realizam no ciberespaço relacionadas à sua aprendizagem escolar.

Para tal, os sujeitos da investigação foram os alunos que apresentaram as características de usuários imersivos e ubíquos ${ }^{3}$, baseados nos estudos realizados por Lucia Santaella $(2004,2013)$. O desenvolvimento de pesquisas nas quais os sujeitos sejam crianças ou adolescentes, pode, além de dar voz à uma faixa etária pouco ouvida, possibilitar melhor compreensão da realidade educacional contemporânea.

A pesquisa realizada, do tipo estudo de caso de cunho qualitativo, se desenvolveu junto a oito alunos do sétimo ano de uma escola da Rede Municipal de Ensino de Florianópolis/SC. A metodologia utilizada foi dividida em dois momentos principais: a aplicação de um questionário online, para os vinte e nove alunos da turma, com objetivo de identificar os perfis cognitivos destes sujeitos, e a realização de um grupo focal com oito alunos identificados com alunos/leitores imersivo e ubíquo, nosso principal

\footnotetext{
${ }^{3}$ Aprofundaremos esses conceitos no decorrer do texto.
} 
público-alvo. A partir do grupo focal identificamos quatro controvérsias que foram descritas e analisadas segundo o quadro teórico da TAR.

\section{A TEORIA COMO MEDIAÇÃO}

O autor Bruno Latour (1994, 2012, 2016), a partir das reflexões realizadas por ele e seus colegas Michel Callon e John Law ao fundarem o grupo de Estudos Sociais da Ciência e Tecnologia (ESCT), enaltece a importância de se investigar as associações que humanos e não humanos realizam, pois ambos são considerados agentes potenciais de transformação.

Estes autores desenvolveram a - Actor Network Theory - ANT, ou a Teoria Ator-Rede - TAR que objetiva analisar as associações que se estabelecem entre os actantes ${ }^{4}$ em uma rede. Rede esta que pode ser entendida como as conexões existentes entre os actantes envolvidos que interferem, influenciam e até modificam o comportamento um do outro, dependendo das associações que estabelecem.

Nas palavras de Latour (2012, p. 15), a TAR procura dissolver a dicotomia que existe entre o humano e o não humano, procura "[...] trazer os não-humanos ao centro do debate sociológico, postular que os mesmos são dotados de agência e que, consequentemente, são atores de plenos direitos nos permite, sem dúvida, entender ainda mais o humano".

Segundo Latour (2012, p. 112-113),

[...] uma ação que arregimenta diversos tipos de forças unidas por serem diferentes. Assim, doravante, a palavra "coletivo" substituirá "sociedade". Sociedade será apenas o conjunto de entidades já reunidas que, segundo os sociólogos do social, foram feitas de material social. Coletivo, por outro lado, designará o projeto de juntar novas entidades ainda não reunidas e que, por esse motivo, obviamente não são feitas de material social. [...] a continuidade de um curso de ação raramente consiste de conexões entre humanos (para as quais, de resto, as habilidades sociais básicas seriam suficientes) ou entre objetos, mas com muito maior probabilidade, ziguezagueando entre umas e outras.

Para a TAR, os papéis dos actantes não são fixos, são as associações que eles estabelecem com o coletivo e o que resulta delas, que merecem ser observadas e descritas, porque são essas associações que mantêm o coletivo em movimento, que fazem com que todos desenvolvam ações e transportem traduções ${ }^{5}$. E tanto faz quem é o responsável pelo movimento, o importante é o movimento acontecer. O coletivo se faz, se desfaz e se refaz a partir das relações desenvolvidas entre os humanos e os não-humanos.

E durante a realização da nossa pesquisa, pudemos perceber que as TD são importantes actantes mediadoras no processo de ensino e aprendizagem dos alunos. Os alunos as utilizam para realizarem associações relacionadas aos conteúdos curriculares. Eles navegam no ciberespaço, entre

\footnotetext{
${ }^{4}$ Termo emprestado da semiótica greimasiana e que significa tudo aquilo que gera uma ação, que produz movimento e diferença, podendo ser humano ou não humano (LEMOS, 2013, p. 42).

5 "Traduzir é ao mesmo tempo transcrever, transpor, deslocar, transferir e, portanto, transportar transformado" (LATOUR, 2016, p. 30).
} 
as informações encontradas, realizando as associações necessárias para se apropriarem, ainda mais, dos conteúdos em questão. Discorreremos mais sobre essa questão, nos resultados obtidos.

Com o advento das TD, conhecer e compreender os alunos e as alterações que ocorrem no seu estilo de vida e na maneira como organizam seus pensamentos e agem sobre o mundo torna-se essencial para efetivarmos práticas educativas coerentes com as novas formas de aprendizagem desses alunos. Dessa forma, poderemos discutir as mudanças que esse momento implica para a escola e para o processo de aprendizagem dos alunos imersos no ciberespaço.

O uso das TD está cada vez mais ubíquo. Podemos usá-las em qualquer lugar e a qualquer hora. A internet, aliada à hipermobilidade ${ }^{6}$, facilita o acesso ao ciberespaço, no qual as informações estão disponíveis e diversificadas, promovendo novas maneiras de interagir com e no mundo, novas maneiras de processar a cultura, a cibercultura (SANTAELLA, 2013).

No ano de 2004, Lúcia Santaella realizou uma pesquisa que investigou como as tecnologias e o uso da hipermídia7 vêm modificando o perfil cognitivo dos sujeitos leitores. Estes, desenvolvem uma nova forma de ler e, inclusive, de organizar o pensamento. Ela identificou e caracterizou três perfis de leitores: leitor contemplativo/meditativo; leitor movente/fragmentado e o leitor imersivo/virtual.

O primeiro perfil cognitivo que a autora identificou foi o do leitor contemplativo, o leitor do livro impresso e da imagem fixa, caracterizado pela leitura silenciosa de um livro ou pela contemplação solitária de um quadro. Este leitor surgiu a partir do século XVI, período em que a leitura era linear, individualizada e ele buscava a informação na biblioteca, seu lugar preferido.

O segundo foi o leitor movente, do mundo em movimento, dinâmico, que surgiu com o jornal e a publicidade. Ele lê imagens na TV, nas propagandas em outdoors e seu interesse pela informação é igual ao tempo que ela é veiculada na imprensa, recortando a realidade.

O terceiro tipo de leitor foi o imersivo/virtual, que surge com o advento da Internet. É o leitor de hipertextos e hipermídias, navega livremente entre os nós e nexos do ciberespaço tornando-se autor e coautor no seu processo de leitura e de busca por informação. Para o leitor imersivo, a leitura é multilinear. Com apenas "um click", ele traz novas informações a sua leitura, seja por meio de outro texto, de uma imagem ou até mesmo de um vídeo (SANTAELLA, 2004).

E ao caracterizar o perfil cognitivo do leitor imersivo, a autora realizou uma distinção entre os tipos de usuários que navegam no ciberespaço: o novato, o leigo e o experto. O usuário novato é aquele que necessita de ajuda para encontrar o que busca; o usuário leigo é aquele que já sabe navegar no ciberespaço, mas realiza apenas ações já memorizadas específicas; e, o usuário experto pode ser definido como aquele que possui habilidade para navegar e realiza ações precisas.

Em 2010, quase dez anos depois de começar seus estudos sobre o perfil cognitivo dos leitores e com o avanço das TD, especialmente das tecnologias móveis, Santaella caracterizou um quarto tipo de leitor: o leitor ubíquo. Este surge com o desenvolvimento das tecnologias móveis, com as práticas da hipermobilidade e hiperconectividade características da sociedade atual. Este sujeito aprende se

\footnotetext{
6 "[...] espaço intersticial, espaço híbrido e misturado." (SANTAELLA, 2013, p. 21).

${ }^{7}$ Hipermídia é a "junção do hipertexto com a multimídia, ou seja, é justamente a linguagem com a qual lidamos quando navegamos pelas informações nas redes." (SANTAELLA, 2013, p. 231).
} 
movendo, a qualquer tempo e em qualquer lugar com o auxílio dos dispositivos móveis, com o seu smartphone. O leitor ubíquo é livre para criar e seguir suas próprias rotas de navegação entre o físico e o virtual (SANTAELLA, 2013).

Enfim, foi nos estudos mencionados acima que nos embasamos para escolher e ouvir os alunos que participariam do grupo focal de nossa pesquisa. Priorizamos ouvir os alunos que, praticamente, nasceram imerso no ciberespaço, ou seja, os que navegam com facilidade no ciberespaço, os que já encontram subsídios para criar as associações necessárias para aprender e complementar sua educação formal.

E foi ouvindo esses alunos imersivos e ubíquos que percebemos o quanto o professor ainda é essencial para o seu processo de apropriação do conhecimento. Por mais que os alunos estejam pesquisando e descobrindo, por conta própria, alternativas para melhor entender os conteúdos curriculares apresentados, eles continuam tendo, na figura do professor, o actante que detém o conhecimento científico e socialmente "válido". Eles solicitam ao professor de sala que ele confirme a veracidade das informações encontradas.

Acreditamos que é nesse momento que a tradução acontece, pois o processo de tradução é o processo contínuo de compor novos significados de acordo com as situações que se apresentam e como elas se apresentam. E, na hora em que eles questionam o professor se as informações pesquisadas estão corretas e o professor reage respondendo, discutindo sobre o assunto, oportuniza que os alunos as transformem em conhecimento.

Tornar o processo de ensino e de aprendizagem mais dinâmico, participativo e colaborativo possibilita que o aluno aprenda fazendo, trace suas próprias rotas de navegação obtendo maior autonomia na busca por informações, no compartilhamento de saberes e na produção de conhecimentos (SANTAELLA, 2004).Na atualidade, percebemos que os estudantes, desde os mais novos, apresentam novas competências e perfis, os quais, necessariamente provocam mudanças na escola. Em uma entrevista concedida a Santos (2015, p. 246), Michel Serres destaca que,

\begin{abstract}
$\mathrm{Na}$ educação, em outros momentos, se tinha apenas a palavra - alguém que cantava ou falava, e era preciso repetir o que ele dizia. Desde o momento que se inventou a escrita, cada estudante podia ter diante dos olhos algum registro do que era ensinado. Logo, a pedagogia mudou, a escola mudou, a partir do instante que houve a escrita. Obviamente, a escola mudou completamente quando surgiu o livro. Por exemplo, se diz que, no momento da Reforma, Lutero afirmava "todo o homem se torna um papa com uma bíblia na mão". Após o livro, não era mais necessário o papa, se estava diretamente ligado a Deus. Portanto, observe tudo se modifica com a invenção técnica da escrita, da leitura, etc. e do digital da Polegarzinha. Por outro lado, a ideia que compõe uma relação pedagógica entre o mestre e o aluno é constante na história. O mestre pode ser um aedo, um cantor, um professor, etc. O suporte modificou-se de forma definitiva, o suporte escrito, o suporte livro ou o suporte digital.
\end{abstract}

Uma nova prática educativa se mostra necessária, na qual alunos, professores e TD se associem em redes para acessarem informações e as traduzirem em conhecimento, apropriando-se de maneira significativa das TD e tornando-se protagonistas na cibercultura, esse novo espaço que é "[...] fruto de novas formas de relação social [...] de novas formas de reencantamento social [...] misturando tecnologia, imaginário e socialidade [...]” (LEMOS, 2015, p. 266-267). 
A partir das associações que fazemos ao nos relacionamos com diferentes actantes das redes as quais pertecemos, é que vamos nos contituindo em actantes também, e mediadores também, e vamos nos transformando e transformamos essas redes.

\section{PRINCIPAIS RESULTADOS: O OLHAR DO ALUNO SOBRE SUA REALIDADE}

De acordo com a TAR, o pesquisador é um importante porta-voz da pesquisa, já que ele fala por todos os actantes envolvidos, ao coletar e descrever os movimentos realizado nas redes. "É como se disséssemos aos atores: Não vamos tentar disciplinar vocês, enquadrá-los em nossas categorias; deixaremos que se atenham a seus próprios mundos e só então pediremos sua explicação sobre o modo como os estabeleceram" (LATOUR, 2012, p. 44).

Com o intuito de contribuir com a produção de conhecimento sobre a realidade no campo da educação, nos propomos a ouvir os alunos de uma escola da Rede Municipal de Ensino de Florianópolis, considerados por nós um dos principais actantes do cenário educacional contemporâneo, pois fomentamos a ideia de que ouvi-los nos permite inserir-nos em seu cotidiano, conhecer e fazer parte do seu mundo digital, e que isso nos ajuda a compreender e repensar como o processo de aprendizagem acontece atualmente.

O nosso método de pesquisa utilizado foi o Estudo de Caso, que consiste em uma investigação sobre um determinado fenômeno contemporâneo inserido em dado contexto da vida real (YIN, 2001). E nosso estudo apresenta características de uma pesquisa qualitativa que investiga e descreve situações complexas que possuem relevância social, a partir da combinação de diversas técnicas de coletas de dados. No nosso caso, aplicamos um questionário online com os vinte e nove alunos presentes na turma, a fim de identificarmos oito alunos com perfil imersivo e ubíquo que fizeram parte do nosso grupo focal.

Ao realizarmos o grupo focal, o problema da pesquisa foi claramente exposto e as perguntas formulada de forma coerentes com o mesmo. Montamos um roteiro, a priori, com quinze perguntas principais que serviram para orientar e estimular a discussão. Como o roteiro foi utilizado com flexibilidade, foi possível a inserção de outras perguntas ao longo da conversa.

Posteriormente à transcrição das falas dos alunos, após várias leituras, releituras e tentativas de recortes, classificação, agrupamento das suas ideias, percebemos a emergência de algumas controvérsias, no sentido proposto na TAR e nossa análise baseou-se nas controvérsias reveladas pelos alunos participantes do grupo focal.

Para a TAR, descrever controvérsias é um ato complexo que, além de exigir tempo e conhecimento sobre o que se quer alcançar com a observação e a descrição proposta, "[...] a controvérsia deve ser reconhecida por todos. Elas são situações nas quais os atores concordam na discordância! [...]" (LEMOS, 2013, p. 113) em que tudo se conecta, de alguma forma, em algum momento. Foi o que identificamos nas falas dos alunos.

As quatro controvérsias identificadas e descritas a seguir, têm como título, afirmações reveladas pelos próprios alunos, uma vez que elas por si mesmas, já indicam este movimento complexo e muitas vezes contraditório vivenciado por eles, em suas associações entre humanos 
(professores, comunidade, colegas, amigos, etc) e não humanos (as redes sociais digitais, os sites, aplicativos, mensagens, plataformas, games, etc) na busca da aprendizagem de conteúdos curriculares, em momentos de realização de atividades solicitadas pelos professores, de pesquisas, de estudo para avaliações, por exemplo.

\section{PRIMEIRA CONTROVÉRSIA: "MESMO PESQUISANDO NA INTERNET EU SEMPRE PERGUNTO PRO PROFESSOR" (JOHN).}

A primeira controvérsia identificada diz respeito ao fato de que os alunos identificados como leitores imersivos e ubíquos estão constantemente conectados, ativos no ciberespaço, e utilizam esse espaço também para o seu estudo escolar, ainda "confirmam", junto aos professores a veracidade das informações que obtêm na internet. Por isso, escolhemos a fala de Jonh como representativa para intitular esta controvérsia.

O ciberespaço favorece a prática de novas formas de ensinar e de aprender. Entretanto, o universo das redes é um espaço em constante transformação. A orientação na busca das informações encontradas é importante para que ela seja traduzida em conhecimento. Nesse sentido, o papel do professor é relevante, pois ele pode atuar como mediador do processo, auxiliando o aluno na escolha dos melhores caminhos a serem percorridos para encontrar o que está buscando e aprender a discernir as informações avistadas.

O acesso às informações está facilitado e a escola deixou de ser o único local de legitimação do saber (MARTIN-BRABERO, 2011), mas isso não significa que esse acesso transforma a informação em conhecimento. É preciso orientar a busca e a tradução (LATOUR, 2016), tradução esta que é essencial para o processo de ensino e de aprendizagem, já que é o exercício de compor novos significados de acordo com as situações que se apresentam e como elas se apresentam. A tradução só terá significado se transformar, se nos fizer, pelo menos, pensar sobre o que foi traduzido.

A nossa intenção com a constatação dessa primeira controvérsia foi salientar o fato de que as TD não substituem a figura do professor, que ele pode e deve assumir o papel de mediador do conhecimento prévio dos alunos e do conhecimento científico, curricular. Claro que, em muito momentos, as próprias tecnologias digitais também assumem o papel de mediador, como afirma a TAR, mas o professor ainda se configura, na percepção e fala dos alunos, no mediador mais "confiável". Segundo o aluno Dimi "Num dia eu vejo o que preciso na Internet e no outro eu pergunto pro Professor se está certo".

Das falas dos alunos, pudemos inferir que, de alguma maneira, eles sabem que o ciberespaço, além de ser um local onde a circulação de informações é livre, onde não há muitas regras para publicações e postagens, qualquer pessoa pode postar sobre o que quiser e da maneira que quiser. Eles percebem que o ciberespaço também é um espaço de informações instáveis, como disse o aluno Pedro: "Eu não acredito 100\% no que dizem não". Esses alunos demonstraram que têm uma atitude reflexiva e investigativa da realidade apresentada nesse espaço, não aceitando tudo o que veem e ouvem como verdades absolutas. Essa controvérsia pode, assim, tornar-se uma ação e atitude a ser explorada pelo professor. 


\section{SEGUNDA CONTROVÉRSIA: “DIFICILMENTE A GENTE DESCE PARA A SI” (DIMI).}

A segunda controvérsia identificada refere-se ao fato de a escola onde a pesquisa foi realizada ter uma estrutura tecnológica e pedagógica adequada para a integração das TD no processo de ensino e aprendizagem. Entretanto, se constatou que a sala de informática é pouco utilizada nos processos de ensino e de aprendizagem.

A escola onde realizamos a pesquisa possui, atualmente, vinte computadores de mesa na SI, cinco chromebook, cinquenta e três tablets, uma lousa digital e um projetor, aparelhos que estão disponíveis para o uso dos professores e dos alunos. Com base nessa informação, podemos verificar que a escola é bem equipada em termos de recursos tecnológicos que, em princípio, estes, podem contribuir para o desenvolvimento das mais variadas metodologias de ensino.

Entretanto, durante a conversa no grupo focal, os alunos verbalizaram que utilizam muito pouco as TD na escola, especialmente com relação ao uso da SI. Segundo a aluna "A", "Se usamos três vezes durante o ano os tablets foi muito. Só me lembro de uma prova que fizemos neles". Ora, o que pode estar provocando essa situação, já que os alunos, em sua maioria, já apresentam novas formas de aprender?

Durante a realização do grupo focal, os alunos questionaram e ficamos nos questionando também: por que não "Nos trazer na SI e ensinar a usar estas coisas, power point, formulários do Google, blogs, vídeos" (Dimi). Ou "Nos ensinar robótica"! (Pedro). Ou criar um aplicativo "Igual ao Projeto que vimos na Feira de Ciências que criaram um aplicativo de estudos, de coleta de lixo." Ou "Fazer músicas. A gente ou o professor cria músicas e vídeos sobre os conteúdos" (Polegarzinha).

Seguindo a linha de raciocínio deles, perguntamos se eles não sugeriam, aos seus professores, maneiras de aprender diferenciados e que integrassem o uso das TD, principalmente dos smartphones. Todos disseram que não, e o Pedro nos explicou o porquê: "Tem aquela lei que proíbe o uso do celular, aí tenho medo de pedir pro professor para fazer isso, porque não pode usar na sala de aula. Essa lei não ajuda muito".

De fato, existe a Lei n. 14.636/2008, que proíbe uso de telefone celular nas escolas de Santa Catarina. E ela está sendo revista. Dia 23 de outubro de 2017, aconteceu uma audiência pública, na Alesc $^{8}$, para debater sobre o projeto de Lei 0198.8/2016 que visa autorizar o uso do celular nas escolas para fins pedagógicos. Esta Lei ainda é um projeto, avançou bastante nas discussões durante esta audiência pública, mas por enquanto não foi aprovada.

Nessa pesquisa, percebemos que os alunos desejam agir de maneira colaborativa com as TD disponíveis, a fim de se associaram e estabeleceram redes de conexões para o processo de ensino e aprendizagem. A aluna Polegarzinha nos questionou "Não tem as lousas aqui? Podiam usar né?! Para mostrar e explicar os conteúdos, mostrar vídeos, imagens". Podia, né?! Mais importante que saber qual ação é desenvolvida nas associações que estabelecemos com os actantes envolvidos, é saber como desenvolveremos essa ação, pois toda ação mediadora é dotada de intenções.

\footnotetext{
${ }^{8}$ Assembleia Legislativa do Estado de Santa Catarina.
} 


\section{TERCEIRA CONTROVÉRSIA: "É DIFÍCIL CHEGAR NELES E SUGERIR COISAS DIFERENTES. O QUE PARECE É, TIPO, QUE ELES GOSTAM DE SEGUIR UMA FORMA TRADICIONAL DE DAR AULA" (DIMI).}

Essa terceira controvérsia surge na fala do Dimi. Ou seja, na atualidade, existem muitas possibilidades para um novo fazer pedagógico, mais compatível com esses novos sujeitos que se caracterizam como leitores imersivos e ubíquos, apesar disso, alguns professores ainda costumam utilizar apenas a voz, o quadro e o livro didático. E mais, numa perspectiva tradicional de educação.

Talvez essa perspectiva tradicional de educação, a que os alunos se referem, se relacione com a abordagem tradicional descrita pela autora Maria das Graças Mizukami. Para ela, a abordagem tradicional é centrada no professor, ele é o transmissor de conhecimento, o aluno é apenas um receptor passivo das informações que Ihe são oferecidas. As aulas são basicamente expositivas, nas quais o professor já traz todo conteúdo pronto, impossibilitando o improviso, a flexibilidade e a liberdade de criação por parte do aluno (MIZUKAMI, 1986).

Quando a ubiquidade aparece, a ideia de espectador e receptor é afastada e a dinâmica do diálogo humano-computador ganha destaque, tornando as situações de aprendizagem mais colaborativas e dinâmicas (SANTAELLA, 2013). Os alunos externaram o desejo de criar, de serem alunos mais ativos no processo de ensino e aprendizagem, princípio importante para o desenvolvimento de uma aprendizagem mais colaborativa e significativa.

Desde muito cedo as crianças estão se acostumando a utilizar as TD, a afinidade das crianças com elas se estabeleceu de forma diferente da estabelecida pelos adultos. Assim, é preciso reconhecer que nossos alunos, que nasceram na Era Digital, têm uma postura diferenciada em relação às TD e à sua função em seu dia a dia. Suas habilidades e estratégias mentais estão se modificando (SERRES, 2015) na medida em que consomem cada vez mais este ou neste mundo digital.

O interesse de cada aluno é o diferencial em qualquer situação de aprendizagem. Independentemente da tecnologia disponível, seja o livro didático, seja o aplicativo no smartphone, o aluno que está motivado a aprender, vai querer aprender. E para despertar o interesse, motivá-los a querer aprender, apostamos no desenvolvimento de uma aprendizagem naturalmente mais colaborativa, na qual a participação dos alunos e dos professores no processo de ensino e aprendizagem ocorra por meio da interação, em que cada um sabe alguma coisa e tem algo a contribuir, consolidando uma ação coletiva de construção de conhecimento. Nessa perspectiva, Ávila e Borges (2015, p. 111) afirmam que

Para esta nova geração, a cibercultura vem proporcionando outras possibilidades, novos espaços onde as crianças e os jovens se procuram e se agrupam em comunidades, buscam mais conhecimentos e soluções para suas dúvidas, com a ajuda de outros, informam-se sobre os acontecimentos do mundo, da sua cidade e dos seus direitos, enfim, uma geração que está fortalecendo uma cultura participativa. 
A escola é um ambiente híbrido, formado por professores, alunos, gestores, salas de aula, laboratórios, SI, TD, regimentos e tantos outros actantes. É nesse ambiente que se forma o social, e os actantes se associam de tal forma que a conexão existente faz com que todos desenvolvam ações e transportem traduções. Buscar novas formas de aprender e de ensinar, integradas às TD disponíveis na escola, possibilita que o aluno aprenda fazendo, torne-se autor e coautor na produção de cultura e conhecimento por meio da criação colaborativa, do diálogo, da socialização e do compartilhamento de saberes e, assim, transforme o processo de ensino-aprendizagem numa postura colaborativa de aprender e ensinar.

\section{QUARTA CONTROVÉRSIA: "NA MAIORIA DAS VEZES ESCONDIDO. MAS A MAIORIA DOS PROFESSORES NÃO LIGA" (PEDRO).}

Nossa quarta controvérsia reporta ao fato de que os alunos da Turma 71 utilizam seus dispositivos móveis com ou sem o consentimento dos professores. Mesmo os professores dizendo que é proibido usar esses dispositivos, os alunos os usam e a maioria dos professores faz de conta que não vê o que está ocorrendo. "Eu uso mesmo se não pedirem, e mostro que estou usando" (Polegarzinha).

Os alunos imersivos e ubíquos ouvidos nesta pesquisa nasceram imersos no mundo digital. Para eles é muito fácil navegar no ciberespaço. O professor precisa desmistificar o uso e buscar utilizar as TD como artefatos digitais facilitadores do processo de ensino e aprendizagem. Não há mais como omitir ou negar o benefício e os obstáculos que as TD podem oferecer a esse processo, devendo o professor se apropriar delas de forma a potencializá-las enquanto artefatos digitais que propiciem situações de aprendizagens significativas e colaborativas, a fim de não se tornar só mais um modelo de ensinar. Nesse sentido, Santaella e Braga (2017, p. 419) afirmam que

[...] aquilo que parece importante, especialmente quando se discute a educação diante das ininterruptas metamorfoses da cultura digital, é se colocar a questão das transformações, sobretudo cognitivas, que essas metamorfoses estão trazendo para a constituição do humano. Afinal, que crianças e jovens são esses que se apresentam ao educador, quando se sabe que as diferenças geracionais nem chegam a alcançar a margem de dez anos, conforme pode ser empiricamente observado em uma criança de dez anos que está mais naturalmente adaptável à chegada de novas interfaces do que um jovem de vinte anos.

A partir de pesquisas realizadas para conhecer e compreender a influência das TD na Educação na Era da Mobilidade, Santaella (2013), cunhou um novo tipo de aprendizagem, a aprendizagem ubíqua ou u-learning (SANTAELLA, 2017), que nada mais é do que as novas formas de aprendizagem mediadas pelos dispositivos móveis. Com um dispositivo móvel na mão, com conexão contínua à internet, podemos ter acesso irrestrito a qualquer assunto, a qualquer momento e em qualquer lugar.

A ubiquidade permite pensarmos novas possibilidades de ensino e aprendizagem, novas possibilidades de tornar a educação mais significativa para o aluno, pois está mais próxima da sua realidade. Entretanto, por mais que a ubiquidade esteja em pauta, a aprendizagem ubíqua não substitui 
a educação formal, ela "[...] desafia a educação formal a buscar estratégias de integração. Como tirar proveito das potencialidades da ubiquidade para o ensino? Como complementar a aprendizagem ubíqua com aquilo que lhe falta e que só a educação formal pode lhe trazer?" (BRAGA; SANTAELLA, p. 2013, p. 27).

No decorrer da conversa com o grupo focal, ficou claro que os alunos têm consciência de que o uso de dispositivos móveis em sala de aula pode desfocar e atrapalhar a aprendizagem e que há alunos que utilizam apenas para lazer. $O$ aluno Baixinho comentou que tem gente que se distrai podendo utilizar o smartphone em sala de aula, mas ressaltou que quem se dispersa é porque é "viciado" em redes sociais porque é possível controlar o uso e focar na aprendizagem: "Tipo, quando eu trago smartphone e tem mensagem, eu penso 'para que ver e responder agora'? A mensagem vai continuar ali, respondo depois!". E a aluna Chuva complementa: "Vai depender da pessoa, se ela participa de muitos grupos ou se não diz 'agora não posso, estou estudando'!”.

Ou seja, os alunos demonstraram entender que, dependendo de como o uso das TD acontece, elas podem contribuir ou não para a Educação. Sabemos que a distração dos alunos pode acontecer em sala de aula, o aluno que não estiver com vontade de prestar atenção na aula não vai prestar atenção. Mas essa pesquisa nos mostrou que essas situações independem da tecnologia que ele tiver na mão. O smartphone não é (ou pelo menos não é o único) "vilão" para a falta de atenção e o comportamento irrequieto dos alunos em sala de aula. Estamos diante de alunos leitores imersivos e ubíquos, e esse tipo de leitor

[...] é dotado de uma prontidão cognitiva ímpar para orientar-se entre nós e nexos multimídia, sem perder o controle da sua presença e do seu entorno no espaço físico em que está situado. Isso só é possível porque o que se tem aí é um tipo de mente distribuída, capaz de processar, paralela e conjuntamente, informações de ordens diversas, dando a elas igual magnitude, tanto as informações que provêm da situação ao seu redor, quanto aquelas miniaturizadas que estão ao alcance dos dedos e que são rastreadas com acuidade visual veloz e quase infalível, como se os olhos adivinhassem antes de ver [...] (BRAGA; SANTAELLA, 2017, p. 421).

Talvez, ao invés de proibir o uso dos smartphones em sala de aula, por exemplo, sob a alegação de que há uma lei que não permite ou que "tem gente que se distrai" (Polegarzinha), iniciemos um trabalho pedagógico voltado à reflexão conjunta sobre quais associações seriam possíveis ao se utilizar os dispositivos móveis em sala de aula. O que queremos revelar com essa sugestão é que as TD não podem assumir uma única essência, de boa ou ruim, pois o uso delas (e de qualquer outra tecnologia disponível) e o impacto que isso trará ao processo de ensino e aprendizagem dos alunos dependerá das ações e das associações que os professores permitirão acontecer.

Buscar formas de tornar a aprendizagem mais significativa talvez perpasse pela tentativa de integrar o uso das TD aos conteúdos curriculares, configurando uma postura mais colaborativa e interativa de aprender e ensinar. E, talvez, ouvir os alunos seja um dos caminhos para identificarmos a que situações de aprendizagem eles estão expostos à medida que desenvolvem ações no ciberespaço relacionadas à sua aprendizagem e, assim, transformarmos nossa controvérsia em uma caixa-preta.

\section{CONSIDERAÇÕES FINAIS}

Reflexão e Ação [ISSN 1982-9949]. Santa Cruz do Sul, v. 29, n. 1, p. 20-33, jan./abr. 2021.

https://online.unisc.br/seer/index.php/reflex/index 
Pensar sobre o ensinar e o aprender é importante para garantir a qualidade da Educação. Por que trabalho com Educação? Onde quero chegar trabalhando com a Educação? Qual é o meu papel enquanto professor? O que faço para aprimorar e inovar minha prática docente? O que me impede de inovar? Quais são os meus objetivos quando planejo minhas aulas? Meus planejamentos são significativos e flexíveis? Que sujeito pretendo formar? Qual a importância dos meios que utilizo para atingir este fim? Por que integrar as TD com a educação? Como e para quê integrá-las de forma realmente inovadora em minhas aulas?

As TD articuladas à Educação parecem ainda não ser a realidade em muitas escolas e, não estão consolidadas no nosso sistema educacional. Transpor o seu uso pessoal para o uso profissional é um desafio a ser superado pelos profissionais da educação. Será que ouvir nosso aluno nos ajudaria a superar as dificuldades de efetivamente utilizar as tecnologias digitais a serviço da aprendizagem e do ensino? Enfim, reflexões para futuras pesquisas.

Agora, com essa pesquisa, destacamos duas controvérsias que, para nós, se constituem em nossos resultados mais interessantes. A primeira controvérsia remonta ao fato de os alunos pesquisarem e descobrirem, por conta própria, alternativas para melhor entenderem os conteúdos curriculares apresentados. Pesquisando no Google, tirando dúvidas sobre os conteúdos, eles descobriram aplicativos de smartphones com conteúdos curriculares. Com isso, pudemos perceber que as TD são importantes actantes mediadoras no processo de ensino e aprendizagem desses alunos.

E a partir dessa primeira controvérsia, surge a segunda a ser destacada: mesmo eles utilizando esses artefatos digitais novos para seu aprendizado escolar, eles continuam tendo na figura do professor o actante que detém o conhecimento científico e socialmente "válido". Eles solicitam ao professor de sala que confirme a veracidade das informações encontradas.

Acreditamos que o papel de validar as informações disponíveis é fundamental que seja assumido pelo professor nos dias atuais. Talvez essa seja uma das principais funções sociais que a escola precisa assumir atualmente. Os alunos demonstraram ter acesso a todo tipo de informação, que é facilitado por meio das tecnologias móveis e ubíquas. Também sabemos - e eles têm consciência que no meio de tantas informações disponíveis e acessíveis, eles podem se deparar com informações equivocadas intencional ou propositadamente, as chamadas fake news.

Diante desse fato, é importante que o professor compreenda que os alunos têm esse acesso e buscam os conteúdos curriculares na web, assim como outros conteúdos, para depois possibilitar que eles desenvolvam uma reflexão crítica sobre as informações adquiridas, problematizando-as, questionando-as. Somente assim tanto o professor como os alunos desenvolverão um pensamento crítico e seletivo relativo a essas informações e construirão, assim, o conhecimento.

As situações de aprendizagem ocorrem de maneira contínua em nosso cotidiano. As TD estão muito presentes no dia a dia das pessoas. Incorporá-las à prática educativa exige que saiamos da nossa zona de conforto, mas, se utilizadas com sentido, podem contribuir de forma significativa com o processo de ensino e aprendizagem, justamente por darem mais sentido a esse processo. 
As associações que são estabelecidas entre os actantes envolvidos podem modificar a prática docente, mostrando que o mais importante não é possibilitar o acesso às tecnologias, mas possibilitar a participação na produção de conhecimento por meio do seu uso.

E para finalizar, gostaríamos de ressaltar que, durante a realização do grupo focal, por diversas vezes ficou subentendida a vontade dos alunos de serem protagonistas do seu processo de ensino e aprendizagem. Eles querem criar. E eles querem usar as TD disponíveis. As TD fazem parte deles, elas são inerentes à maneira como agem, como falam, como se divertem e como estudam.

\section{REFERÊNCIAS}

1. ÁVILA, Silviane de Luca. BORGES, Martha Kaschny. Modernidade líquida e infâncias na era digital. Cadernos de Pesquisa da Universidade Federal do Maranhão, v. 22, n. 2, 2015, p. 102 114. Disponível

em: <http://www.periodicoseletronicos.ufma.br/index.php/cadernosdepesquisa/article/view/3220/2053>. Acesso em: 14 ago. 2018.

2. BORGES, Martha Kaschny. Educação e cibercultura: perspectivas para a emergência de novos paradigmas educacionais. In VALLEJO, Antonio Pantoja, ZWIEREWICZ, Marlene (org). Sociedade da informação, educação digital e inclusão. pp, 53-86. Florianópolis: Insular, 2007.

3. LATOUR, Bruno. Jamais fomos modernos. São Paulo: Editora 34, 1994.

4. LATOUR, Bruno. Reagregando o social: uma introdução à teoria Ator-Rede. Salvador: Edufba, 2012.

5. LATOUR, Bruno. Cogitamus: seis cartas sobre as humanidades científicas. São Paulo: Editora 34, 2016.

6. LEMOS, André. A comunicação das coisas: teoria ator-rede e cibercultura. São Paulo: Annablume, 2013.

7. SANTAELLA, Lúcia. Navegar no ciberespaço: o perfil cognitivo do leitor imersivo. São Paulo: Paulus, 2004.

8. SANTAELLA, Lucia. Comunicação ubíqua. Repercussões na cultura e na educação. São Paulo: Paulus, 2013.

9. SANTAELLA, Lúcia. Desafios da Ubiquidade para a Educação. São Paulo/SP: Revista Ensino $\begin{array}{lllll}\text { Superior } & \text { UNICAMP, } & \text { abr } & 2013 . & \text { Disponível }\end{array}$ 
<https://www.revistaensinosuperior.gr.unicamp.br/artigos/desafios-da-ubiquidade-para-aeducacao> Acesso em: 14 ago. 2018.

\section{Diane Schlieck}

Possui Graduação em Pedagogia pela Universidade Federal de Santa Maria/RS (2002), Especialização em Tecnologias em Educação, pela Pontifícia Universidade Católica do Rio de Janeiro/RJ (2010) e Mestrado em Educação pela Universidade do Estado de Santa Catarina/SC (2018), sob a orientação da Professora Doutora Martha Kaschny Borges, na Linha de Pesquisa Educação, Comunicação e Tecnologia, no Grupo de Pesquisa Educaciber. Em 2005, tornou-se Professora do $2^{\circ}$ ano da Escola dos Sonhos, rede provada de Florianópolis. No ano de 2009, efetivou-se na Rede Municipal de Ensino de Florianópolis como Auxiliar de Ensino, onde coordenou a Sala Informatizada, da ED Jurerê, por dois anos. Em 2011, efetivou-se novamente na Rede Municipal de Ensino de Florianópolis, como Professora de Ensino de Tecnologia Educacional, na EBM Intendente Aricomedes da Silva, onde trabalha até hoje. Ganhou o Prêmio "Professor Nota 10", em 2013 e 2015.

\section{Martha Kaschny Borges}

É graduada em Pedagogia pela Universidade do Estado de Santa Catarina (1991), mestre em Educação pela Université Pierre Mendes France II (1998), mestre em Educação pela Universidade Federal de Santa Catarina (1997) e doutora em Educação pela Université Pierre Mendes France II (2001). Foi Presidente e Diretora Técnico-Científico da Fundação Escola de Governo ENA. Atualmente é professora titular da Universidade do Estado de Santa Catarina, professora permanente dos Programas de Pós-Graduação em Educação - PPGE/UDESC e em Administração - ESAG/UDESC. Realizou Estágio Pós-Doutoral na Université Aix-Marseille, França e Estágio Pós-doutoral na Universitat de Barcelona, Espanha, em 2015. Foi professora convidada da Università dgli Study di Firenze. Tem experiência na área de Educação, atuando principalmente na linha de pesquisa Educação, Comunicação e Tecnologias, com os seguintes temas: Educação e Cibercultura, Tecnologias Digitais na Educação, Teoria Ator-Rede, Formação de Professores, Processos de Ensino e de Aprendizagem na Cultura Digital.

\section{Como citar este documento:}

SCHLIECK, Diane; BORGES, Martha Kaschny. APRENDIZAGEM ESCOLAR NO CIBERESPAÇO: CONTROVÉRSIAS REVELADAS POR ALUNOS(AS) DO ENSINO FUNDAMENTAL. Reflexão e Ação, Santa Cruz do Sul, v. 29, n. 1, p. 20-33, jan. 2021. ISSN 1982-9949. Acesso em: doi: http://dx.doi.org/10.17058/rea.v29i1.14283 